\title{
ASIA PACIFIC BUSINESS REVIEW
}

\section{OLD AND NEW RURAL CO-OPERATIVE MEDICAL SCHEME IN CHINA: THE USEFULNESS OF A HISTORICAL COMPARATIVE PERSPECTIVE}

\author{
ANDREA BERNARDI \\ Senior Lecturer in Organization Studies, Manchester Metropolitan University \\ Oxford Road, Dep. Management, Manchester M156BH, UK \\ Email: a.bernardi@mmu.ac.uk (corresponding author) \\ Formerly University of Nottingham Ningbo China
}

\begin{abstract}
ANNA GREENWOOD
Associate Professor of Colonial History, The University of Nottingham, 199, Taikang East Road, Ningbo, 315100, Zhejiang Province, China

Email: anna.greenwood@nottingham.edu.cn
\end{abstract}

\begin{abstract}
This work compares the health cooperatives fêted in Maoist China in the 1960s to the New Rural Medical Co-operative Scheme (NRCMS) that has been operating in China since 2002. Organisational and ideological similarities between the old and new co-operative medical schemes are described. By mapping continuities and discontinuities in the way the co-operative organisational model has been deployed under different contexts, we argue for the usefulness of blending historical method and organisational analysis as a means of understanding some of the challenges of contemporary Chinese social policies. Using this technique of historical comparison, this work concludes that the NRCMS, despite being different in orientation, is still affected by political influences, and organisational traits, evident within its former incarnation. This acknowledgement, we argue, has important implications for policy and practice today.
\end{abstract}

KEYWORDS: China, Co-operative, Healthcare, History, New Rural Co-operative Medical Scheme, Organisation. 
One of the challenges of China's booming growth in the past few decades is the search to find an affordable and effective means of providing equitable medical care to the millions of rural inhabitants who constitute almost half of the total population of China. To this end since 2002, the Chinese government has sought to implement a New Rural Cooperative Medical Scheme (NRCMS), providing basic medical insurance to the majority poor in return for annual membership payments. This scheme was not entirely new and was broadly based on an older scheme of co-operative rural healthcare (the Rural Co-operative Medical System) formally inaugurated by Mao Zedong in 1965. Understandably given the large differentials, in terms of market and political contexts, which have evolved between 1965 and 2002 these two schemes demonstrate key differences. Perhaps most prominently, while in the past the health co-operative was given a degree of autonomy in terms of organising its own local structures and medical services, today, the NRCMS is more obviously voluntary and centrally led, comprising to all broad intents and purposes an imitation of a western-style mutual scheme whereby individuals can invest in return for basic health insurance.

Today the NRCMS initiative is proudly displayed by Chinese health policy makers as one of the cornerstones in the development of a sustainable health framework for contemporary China. This position has been most recently exemplified by the public announcements to introduce new pilot pension schemes in Shanghai and Beijing as a means to address the financial burdens on its rapidly aging population (UNDP, 2013). With huge challenges ahead of China with its large and unequal population, health care policies have been in the public eye as never before; capturing the attention of not only academics, but also social and political commentators within both governmental and international organisations.

The motivation behind this study is to understand the differences and similarities between the two incarnations of this health scheme. For all of its claims for modern relevance, the NRCMS is, we believe, strongly historically rooted with Maoist policy. It is perhaps a surprising choice for the government of China to so obviously resurrect a scheme from a past that in many ways it choses to forget, but what is even more surprising is that scholars have not studied the meanings and implications of these continuities and discontinuities (in ideology and organisation) with the past. This presents a large gap in the literature of analysis of Chinese health provision and highlights the importance of the past as a tool to better understand both the present and the future. Despite inherent difficulties in comparing dissimilar contexts, particularly when the political and socio-economic landscapes have 
changed as much as they have in China, a glance historically backwards can, and regularly should, offer useful insights.

Additionally we argue that the use of historical perspectives can have very tangible relevance for practice and research. To this end, our work extends non-comparative studies of the co-operative medical system in China (for example, Zhang, H., 1982 and Xia, 2003; Yip and Hsiao, 2009; Babiarz et al., 2010; Qin et al., 2012; Dong et al., 2013) and also adds a new dimension to other academic works examining the modern health problems of China (Wagstaff and Lindelow, 2005; Wang, 2008; Wagstaff et al., 2009). Additionally it will supplement understandings about the development of the co-operative ideal in China (ChengChung, 1988, Gao and Chi, 1996). Two research questions are to be explored:

1. To what extent can both the old and the new Rural Co-operative Medical Schemes (RCMS) be seen as ideologically similar?

2. To what extent is the new organisational approach of the NRCMS similar or different to western models of mutual insurance?

We stress from the outset that this research is firmly historical, offering new perspectives to contribute to and extend already existing work within the Chinese and international literature on health care, co-operatives, management and economic policy in China. The method therefore is principally one of qualitative textual analysis of both primary and secondary literature on the topic. It is based on extensive archival research undertaken in both historical and contemporary Chinese and English source material, including research at the World Health Organisation (WHO) archive, Geneva, and original documental research undertaken in China. The data collection took place between 2009 and 2013 when both authors were employed in an academic institution in China. This made it possible to visit a number of co-operatives and hold discussions with co-operative leaders and members in the Beijing, Shanghai, Hong Kong, Zhejiang, and Guangxi areas. It was conducted as part of a larger research project on Chinese co-operatives. The archive work has uncovered data never analysed before with this comparative historical perspective, and has never been subjected to organisational analysis.

The co-operation of History and Organisational Studies to the understanding of contemporary Chinese policy presents something original in itself, as although crossdisciplinary analysis has become more favoured in recent years (Wadwani and Bucheli, 2013; Rowlinson et. al., 2014; Greenwood and Bernardi, 2014) the need to look back at organisational developments historically is nevertheless still far from assumed behaviour. To this end, the techniques of analysis deployed are both historical and sociological with the 
joint authorship also reflecting the truly cross-disciplinary nature of this endeavour. Additional to the historical approach, Institutional Theory is also used as a secondary-level analytical tool to explain how Chinese co-operatives have been deeply shaped by the socioeconomic transition and the political contingencies.

Given the predominantly historical nature of this work, it is necessary to separately outline the contextual circumstances and subsequent literature around each health cooperative scheme. Section 2 presents the literature review and the data on the old RCMS. Section 3 presents the literature review and the data on the NRCMS. Section 4, 'data analysis', compares the old and the new systems, answering in turn our two central research questions. In section 5, 'discussion”, we argue for the usefulness of the historical method in organisation studies. There, we also consider the limitations of this study and the need for further research. Section 6, presents the implications of this research for theory development, for practice and policy. Short conclusions follow in section 7. 
THE RURAL CO-OPERATIVE MEDICAL SYSTEM (1934-1981)

The modern co-operative model arrived in China (comparatively late compared to Europe) in the first decade of the twentieth century from England, Japan and Germany based directly on their experiences of co-operative farming and banking (Fairbank and Feuerwerker, 1986). Chinese intellectuals and practitioners with western education developed a local cooperative movement with the active support of western expatriates and missionaries (Cook and Clegg, 2012).

Although small-scale singular examples existed in the early years of the twentieth century, the concept took some time to be established, with the first co-operatives in China, established in 1912. Despite this cautious start, however, during the first two decades of the century intellectuals, politicians and social reformers (Sun Yatsen had a Christian education) increasingly tried to disseminate the co-operative ideal in China, just as intellectuals and elites had disseminated it in Europe in the previous century. A particular turning point can be identified in 1939 when, stimulated by war-time exigencies, co-operatives were embraced as part of the 'Gung Ho' movement proposed in Shanghai two years before. Gung Ho's central principles were of voluntary organisation, self-funding, self-governing, independent accounting, democratic management and distribution to each according to his/her work and dividends according to shares. The accession of Mao and his now famous programme of collectivisation (commenced 1958) meant that the Chinese co-operative movement suddenly changed and began to embody deviations from the original western notion of co-operative firm and co-operation. This is therefore not just a history of the development of co-operatives in China as an alternative business model, but rather is a story of how a model was adapted to suit a regime and to mesh with changing political intrigues.

In terms of health co-operatives specifically, it is notable that the idea (Scott, 2003) of organising healthcare in this way also had a pre-history. Indeed, it can be seen that for at least 30 years previous to the launch of Mao's scheme, health co-operatives were being seriously investigated as a sustainable possibility. In fact, the first call to reform rural healthcare provision system occurred during the early 1930s, with a regulation by the Department of Health coordinating and integrating rural public health passed in 1934 (Zhang, H., 1982, p.24). Although the chief objectives were agreed in principle at this early stage it was not until 1937 that a national medical scheme of this type was formally enacted through legislature. It may seem ironic that the idea officially adopted in 1965 by the Communist Party originated within the nationalist Kuomintang (KMT, or Chinese Nationalist Party). 
In 1945 Mao announced his intention to 'follow the co-operative route' in terms of his healthcare reforms (Mao, 1991, p.1078). ${ }^{1}$ Correspondingly, by 1950, the then Deputy Minister of Health, He Cheng outlined at the first National Health conference, that without serious attention paid to problems of disease and sanitation the 'national production and construction and people's peaceful life cannot be ensured'. ${ }^{2}$ Thus in the political rhetoric health became formally intertwined with nationalist discourses of strength and survival from early on.

In 1956, the Third Session of the National People's Congress adopted the document 'The Regulations of the Practice of Advanced Agricultural Production Co-operative Model'. Here it was stipulated that co-operatives should be responsible for the care of members who had become wounded or ill during work. This seems to have been the spur for further action, as after this medical units, based on either the collective economy or on the combination of collective and individual funding, began to develop in many rural areas. During the period from the foundation of PRC to the late 1950s, a coherent rural co-operative medical care plan was formed mainly out of the experiences of local areas. In November 1959 in Jishan County in Shanxi Province, the Ministry of Health held the National Rural Health Conference, in which the adoption of the system was formally affirmed (Cai, 2009).

The final impetus to turn the rhetoric into action seems to have come from the broader political momentum to set up agricultural production co-operatives as the cornerstone of the People's Commune. To this end, through the Great Leap Forward, millions of Chinese peasants who moved into collective farms were said to move from an agrarian economy into a modern communist society. These communes needed healthcare services and it seemed logical to also organise these, like production, around the fundamental organisational model of the co-operative (Mao Z. 1956: 1958). Before the scheme came to fruition, several trials were undertaken at a provincial level, notably, the Ding County Test and the Shaanxi-GansuNingxia border drug agency (Qiao, 2004). Stimulated by posted reports over the success of these trials, Mao took the issue further when in 1960 he published his Instructions for Public Health (Mao Z., 1960). This began by emotively regretting the inattention made to date on public health issues and stated that people should 'rekindle the patriotic public health movement which has been left behind during the Great Leap Forward, and be sure that achievements are to be made within the period from 1960 to $1962{ }^{3}{ }^{3}$ The solution proposed was to convert all existing health services into a collectively owned model. It was also partially a response to the severe criticisms the Department of Health had been under as the 
available health services had been largely confined to the elite urban-based population $(\mathrm{Xu}$, 1997). ${ }^{4}$

The scheme was launched on 26 June 1965 with Mao giving his famous speech 'Directive on Public Health' (Mao Z., 1965). Within the next months, the Department of Health issued its supportive statement entitled 'Report Prioritizing Primary Level Medical Services to Rural Areas' strenuously pointing out that 'more than 80 per cent of China's population are farmers, if the medical and health problems of these farmers cannot be dealt with seriously, the socialist health policy will come to nothing' (Department of Health, 1965).

In September in 1965, the central committee of the Communist Party of China approved the document 'A Report Concerning Putting Emphasis on Medical Care in Rural Areas' and sent it to the party committee of the Ministry of Health. Following this lead, by the end of 1965, medical co-operative systems were initiated in Shanxi, Hubei, Jiangxi, Jiangsu, Fujian, Guangdong and Xinjiang provinces and shortly after were started all over China. The scheme was successfully propagandised nationwide via publications like the People's Daily and the Newspaper of Health (an official newspaper run by the Department of Health). By 1976, it was estimated (although this is an official, and therefore unreliable, estimate) that $90 \%$ of peasants participated in the co-operative medical care system nationwide. In Figure 1 it is possible to observe the fast rise and decline of membership to the RCMS.

FIGURE 1 ABOUT HERE

Although coverage was extremely good during the 1970s (another estimate in 1975 estimating that 84.6 per cent of the rural population of China was covered by this medical system) (Zhu, 1989, p.431-441), official discussions at a conference of barefoot doctors in Shanghai still quietly acknowledged that more could still be done and 100 per cent coverage was never achieved (Department of Health, 1976). Nevertheless in the middle of the 1970s around 5 million staff participated in the RCMS, of which 1.8 million were barefoot doctors (Annex 5), 3.5 million other health personnel and 0.7 million midwives, making it undoubtedly the centrally most important medical scheme of China (Zhang et al., 2002, p.28). It was an army in dimension as well as in organisational design. Horn described the barefoot doctors as 'a million-strong army' (Horn, 1975, p.22). The system at its peak comprised a 
huge branching system of ambulatory, provincial and local health management intertwined with the local organisational structures of the Chinese Communist Party (CCP). At its peak, in the mid-1970s, it involved millions of personnel and covered $90 \%$ of the country (Shaoguang, 2008, p.14).

In December 1979, the Ministry of Health, Ministry of Agriculture, Ministry of Finance, and the State Pharmaceutical Administration of the National Federation jointly issued the document 'The Regulation of Rural Co-operative Medical Care Service'. This converted the majority of the co-operative medical care institutions into private clinics of village doctors. According to the survey of the 45 counties in 10 provinces in 1985, the peasants' participation rate in rural co-operative medical care had dropped dramatically to only $9.6 \%$, while $81 \%$ of the peasants paid for medical care at their own expense. In 1986, only $5 \%$ of the villages nationwide supported the rural co-operative medical care system, including the suburbs of Shanghai, Zhaoyuan County in Shandong Province, Wuxue County in Hubei Province, Wu County in Jiangsu Province, Wuxi and Changshu. Although some attempts were made to revive the model it was to take until 2002 for it to return with any political force, revamped and revived.

But although the scheme died a fairly conclusive death in China by 1981, this did not mean that interest in the scheme diminished globally. Indeed, significant international interest can be identified during the 1970s and 1980s, as other nations and health organisations looked for new ways to deliver healthcare to rural populations, a drive particularly motivated by the WHO's goal of Health for All by the Year 2000. Indeed, as one report suggested, 'the time was ripe for the Chinese model and method to be hailed as the ideal' (Skeet, 1984, p.292). Throughout the 1970 s and 1980s the WHO $(1974,1988,1989)$ conducted a series of study missions to China publishing widely on the RCMS potential merits (Bryant 1978, pp.144-48; Li, 1985; Prescott and Jamison, 1984; Lambo, 1980). It seemed that even though the system had flaws (usually pinpointed as the fact that it operated under an oppressive political regime), it contained within it a centrally viable kernel of an organisation model to apply to rural healthcare provision in other national contexts.

Given this international interest and enthusiasm the rapid decline of the RCMS needs brief mention. At first the decline of the RCMS did not seem at all inevitable with the new Constitution of the Republic of China of 1978 specifically stipulating that provision should be made for the co-operative medical service (PRC, 1978, p.44). Quite quickly, however, the tone changed from one that presumed continuity to one that advocated change. Particularly the experiences of one County, Xiangxiang, were widely cited as evidence that farmers were 
not able to shoulder their current burden (Central Political Bureau, 1978). After this initial declaration, other provinces quickly followed the route, also stating that they found the economic burden of the RCMS too heavy (Zhang, 1982, p.31-33; Wang, 2008). The decline was rapid - by 1985 only 39.9 per cent of the rural population in China were covered by the scheme. A substantial drop since the 1970 s, not least as the rural population had grown by nearly 14 per cent between 1975 and 1985 (Zhu et al., 1989, p.431-441).

The reasons for the decline have been the subject of much debate, with most scholars identifying political and economic changes as the root causes (Jamison et al, 1984; Huang, 1988, Young, 1989, Yu, 1992, Bloom and Gu 1997a). After the 1980s the restructuring of the Chinese rural economy individual production became prioritised over collective production, thereby increasing the pressure on peasants to devote themselves to farm work and deincentivising participation in the scheme (Zhu et al., 1989, pp.431-41, p.433). Crucially, central support was perceived to have gone - thereby robbing the scheme of the 'political will, national commitment and community involvement' essential for its success (WHO, 1988).

All three institutional pressures to conform (Scott, 1995; Suchman, 1995), coercive, normative and mimetic isomorphism, had suddenly gone. Mao became very rapidly a controversial figure and the allegiance to him and the previous scheme disappeared (normative), the rigid central supervision on the system declined (coercive), along with the dramatic declination in the need to strictly correspond to the overall collectivist structure (mimetic). We would add to this the impact of Deng's reforms, particularly those that dealt with the ownership rights system that saw no place for this organisational model. 


\section{MODERN VISIONS OF THE NEW RURAL CO-OPERATIVE MEDICAL SYSTEM}

After many years of inaction on behalf of the Chinese government, finally the catastrophic implications of ignoring rural health were acknowledged and in October 2002 at the China National Rural Health Conference, the model for the NRCMS was announced (Klotzbücher et. al., 2010). It is unsurprising that the way the new scheme was presented was one which stressed its progressive modernity and was keen to present it, despite its roots and its name, as far removed from the old Maoist model. The system was publicised as predominantly a mutual health insurance scheme (Brown et al., 2009), such as frequently existed within the contemporary western context (the French case for instance, although this was not monopolistic as the Chinese one was going to be). Its Chinese predecessor, as explained in section 2, was a huge structure in charge of health care operations such as the management of the medical practice, the organisation of pre-emptive public medicine works in the villages, the production of herbs and the training of barefoot doctors.

The impetus behind this urgency for change and reform is clear. Figures two and three show the gap of opportunities between members of the rural and urban populations in China. The economic success of the most privileged areas of development in coastal provinces and urban areas made this rural problem all the more visible. It must be noted though, that Figure two also represents an improvement since 2009.

FIGURE 2 ABOUT HERE

FIGURE 3 ABOUT HERE

This scheme was to comprise nine new directions for national health policy, most importantly promising central subsidization of healthcare for all. As such China declared its intention to work towards a social insurance model, as opposed to other alternatives (such as private insurance or full direct government financing). In its current incarnation the scheme is heavily subsidized at both central and county levels, essentially using tax revenues to 
supplement household contributions (payable by all members at a flat rate accept the very poor).

In October 2002, it was pointed out in the document "The CPC Central Committee and the State Council's Decision on Further Strengthening Rural Health Work" that "China aims to gradually establish a new rural co-operative medical system." Here the plan for the scheme to unfold was outlined in detail, projecting the hope that "by 2010, rural residents should be involved in the new rural co-operative medical care system generally." The scheme promised from 2003 that:

"the central finance department will provide RMB 10 per person annually for those farmers who participate in the new rural medical care system in the middle and western China. Local financial departments should provide at least RMB 10 financial subsidies for those farmers who participate in the new rural medical care system" (CPC Central Committee and State Council, 2002).

By December 2004, a total of 310 counties nationwide participated in the new rural co-operative medical care system. By March 2009, see figure 1, the coverage of the new RCMS was said to have reached 830 million people. This seems impressive, even if we accept the unreliability of government statistics.

In accordance with the requirements of the " $11^{\text {th }}$ Five-Year Plan", at least $80 \%$ of rural areas were expected to participate in the new rural co-operative medical care system in 2010. On February 17, 2011, the Chinese government released the document "The Arrangement of Five Key Reforms Concerning Medical and Health Care System in 2011". This document pointed out that the government would raise the financial subsidies for peasants' medical care from RMB120 per person annually in 2010 to RMB 200 per person annually in 2011. In 2012 government budget at all levels raised the financial subsidies for peasants' medical care from RMB 200 per person annually in 2011 to RMB 240 per person annually. In Table 1, it is possible to observe some key trends of wealth and well-being before and after the introduction of the NRCMS.

TABLE 1 ABOUT HERE 
If we look at Table 1 considering the curve displayed in Figure 1, mapping the four stages of decline and growth of the RCMS, it is clear that from 2005 the private expenditure on health (as a percentage of total expenditure on health) declined. The public involvement had risen, though the total expenditure on health (as a percentage of gross domestic product) remained rather stable between 1999-2009. This information should be considered together with our knowledge that the per capita government expenditure on health had been raised much less than the per capita total expenditure on health. This suggests that other actors, different from individuals and the government, are now contributing to finance the system: for instance the local authorities or their agencies.

Nevertheless, the scheme has not been unequivocally successful (Qin et al., 2012; Dong et al., 2013). A study found that while the NRCMS reached more people (Wagstaff and Lindelow, 2005; Wagstaff et al., 2009) and gave them access to better medical facilities and technologies, in fact the expense of medical care per visit tended to be higher than previously.

The increase of healthcare costs is a trend common to most nations, particularly those with ageing populations, the public regulation or intervention in health care insurances is a very current and complex topic (Gertler and Gruber 2002). In the Chinese case, some bad practices (for instance the excessive use of antibiotics and over referring as a means of making more profits seem to have made the situation worse. Several studies have monitored the effectiveness and the efficiency of the scheme in contemporary China (Babiarz et al., 2010; Yip and Hsiao 2009; Dong et al., 2013). This situation meant that despite heavy government subsidization, people (especially the poorest groups of society) were actually more out of pocket than they had been under the old scheme. This meant that the poor, cognisant of this extra expense, were less likely to seek this sort of formal medical care (Wagstaff et al., 2009; Wang et al, 2005). Furthermore Liu has argued that the leadership currently offered by the Chinese government for the scheme is still not strong enough, without this, he argues 'China will not be able to establish a sustainable rural health insurance system' (Liu, 2004, p.164). The assessment of the first decade of NRCMS is not yet clear. The United Nations, for instance, by way of contrast recently wrote that:

"Policies implemented in the new century, including the rural tax reform, the policy for rural compulsory education, the new rural co-operative medical care and medical assistance policy, and the new insurance policy for rural old people, have all played their roles in rural poverty reduction and provided policy support for China's achievements in poverty reduction.” (United Nations, 2013, p.12). 
DATA ANALYSIS: COMPARING THE PAST AND THE PRESENT

Turning now to our research questions: what insights does this historical analysis give us? To this end, we have considered it important to build from the archive work our organisational analysis of the past and present RCMS, as suggested recently by Decker (2013) and Wadwani and Bucheli (2013). It is instructive to map the differences and similarities between past and present models of health co-operatives in China. Broadly these can be divided into two categories: firstly the differences in the political climate in which both schemes variously operated, and secondly (but connected to the first point) the way the organisational remit and structure of the system has been altered to fit this changing context.

1. To what extent can both the old and the new Rural Co-operative Medical Schemes be seen as ideologically similar?

The NRCMS clearly was different in some of its fundamental orientations and approaches. Most prominently it was now very much recast as a voluntarily participatory insurance scheme, which although clearly had funding and support from central government, nevertheless was far distanced from the old RCMS model that had been specifically tailored to fit the political ideals of collectivisation and its associated needs for production. All studies of the RCMS in the 1960s have centrally acknowledged the strictures put upon it by the political context in which it operated. The first WHO study mission to China noted (Annex 5) that it felt there was 'no mystery' in the success of the RCMS that was based 'on the rational utilization of resources locally available and on the mobilization of the masses. ${ }^{5}$ As the first article of the Code of Conduct stated: 'RCMS is a socialist medical system built by the members of People's Commune on the basis of voluntary and mutual help. It is collective welfare services for commune members (DAHF, 1980, p.62). ${ }^{6}$ In short, the RCMS was fully integrated with the wider political organisational units of the state. This immediately raises questions of true freedom and autonomy. As scholars of socialist systems have already mentioned in other contexts (Kornai and Yinggyi, 2009; Tsoukas, 1994, p.33), when membership was obligatory and allegiance to the State essential (Shenkar, 1996), to what extent can this be conceived as a true co-operative in the western conceptualisation? Can the barefoot doctors within this structure be accurately seen as free agents working for the community, when ultimately how they worked and where they worked needed to be within the constraints of party political acceptability? Is there a central problematic in being both a disinterested doctor and an interested party member? What is clear is that the Maoist government clearly stated that their preference in terms of recruitment of barefoot doctors was for 'children of the poor and lower-middle peasants': in short stipulating that candidates 
needed to be loyalists to be selected for the role (Zhang et al., 2002, p.25). ${ }^{7}$ In accord with this, the clearly-stated mission of the RCMS was to promote favoured party strategies, so for example, barefoot doctors were explicitly told to promote the one child policy, see Annex 2 (DAHF, 1980, article 3 points $1 \& 6$, p.62). It must be noted that the largest federations of cooperatives in China, for instance All China Federation of Supply and Marketing Cooperatives, were (and still are) directly influenced by the state authorities.

When we examine the situation in which health co-operatives originally flourished in China we find ourselves in an entangled web that integrates healthcare and CCP politics even at the most local level, despite the government rhetoric, which celebrated the way this scheme allowed considerable community self-management. The stated mission of the RCMS explicitly sustained the government's priority of supporting production (DAHF, 1980). As Article 10 of the Code of Conduct of the RCMS stipulated in 1979: 'co-operative medical facilities at each level should be collective welfare units, they should not be run as enterprises or side-line business and should not be required to hand in profits' (DAHF, 1980, p.63). ${ }^{8}$ In the simplest terms, the RCMS provided the first basic tier of healthcare provision available to rural Chinese people as part of their collective farming units. Significantly, the role of the Barefoot doctor therefore was very publically interwoven with that of the regime it served. As a local observer was recorded as pointing out: barefoot doctors were referred to by their patients as 'tongzhi' (comrade) rather than as 'yisheng' (doctor) (WHO, 1978, p.94). They served as an interface between community and government and became a commanding socialist symbol of power and knowledge in the hands of the proletariat, of self-management and the collective ideas of community self-help.

A common organisational pathology, the means-end inversion (Crozier, 1963; Merton, 1936), can therefore be seen in the Chinese context as caused by this central problematic role of ideology and politics running through most organisational endeavours. This in turn brings to mind frequent examples of ineffectiveness and inefficiency that have characteristically plagued state-dominated institutions (Scott, 1995; Shenkar, 1996; Tsoukas). There is no doubt that the original RCMS exemplified leadership patterns, managerial styles and decisionmaking processes primarily shaped by their explicit ties to the Maoist State but also because of Chinese ideals of man fundamentally different to those in the West (Ho, 1978).

We can answer the first question by concluding that the explicit ideological mission has disappeared from the NRCMS. Observing the posters in the rural clinics that we have visited, accessing the official documents and reading the national and international literature, it seems that this propaganda side is certainly less openly declared as part of the scheme's 
mission. During our fieldwork (Annex 3 and 4), visits to the clinics belonging to the NRCMS showed us that advertisements for the new system stressed the individual's responsibility to utilise health insurance, guided by state help and advice. This contrasts with the old-style health propaganda posters ${ }^{9}$ for the RCMS, which emphasised the scheme as a cornerstone of the broader scheme of collectivisation (Landsberger and van der Heijden, 2009, p.186). Here health provision was closely wound up with the necessity to have a population that could maintain production, with figurative depictions of barefoot doctors clearly keen to represent them as comrades and workers. Today the tone has a subtler message of individualism, emphasising that Chinese people need to have access to specialists and hospitals and medicines, a message underscored (although never explicitly stated) with the WHO/UN ideals of good health access as a basic human right.

Local authorities and local political leadership have more autonomy and flexibility in applying national policies or in finding innovative ways to meet national goals. It is still true that local doctors are supposed to work towards, sometimes controversial, national policies such as family planning, but today's rural doctors are a dim reflection of the centrally organised Maoist Barefoot Doctor.

2. To what extent is the new organisational approach of the NRCMS similar or different to western models of mutual insurance?

Perhaps the most dominating difference between the old and new incarnations of the scheme was that the NRCMS emphasized the responsibility of the central government for its funding in a way the earlier scheme never did. Investment from the governmental budget increased from 1.5 billion in 2004 to 3.5 billion in 2006 (Central Committee of the CCP and State Council, 2002). Furthermore, NRCMS differed significantly in emphasis because it focused on paid contributions to join the scheme. This also protected the scheme from financial ruin. What makes the more recent scheme additionally distinctive, however is that it was also put in place in some urban areas, though with a different infrastructural emphasis (since the cities are already provided with hospitals) and with a different financial contribution system, reflecting the higher cost of care (Brown and Theoharides, 2009).

This modern focus upon centralisation and reliance upon government funding is in contrast to, at least the rhetoric of, the original RCMS. Indeed, the RCMS that operated under Mao prided itself on its local flexibility and reliance upon self-management. Even if ultimately all services were rendered as part of the Maoist regime, the RCMS was locally 
able to organise the cultivation of natural plant remedies, the management of physical structures, the selection and training of staff, and the construction of public health facilities such as village draining systems.

On one hand it can be seen that the way that the RCMS was conceived and organised reflected both the centrality of the state and the priorities given to local collective decisionmaking, one that seemingly affords precedence to the decisions of the local community above those of the remote central government. Perhaps this emphasis is most directly illustrated in Article 4 of the Code of Conduct of the RCMS: 'The form of the conduct of RMCS should be based on the local conditions and full discussion of the people's commune members' (DAHF, 1980, p.62). ${ }^{10}$

Similarly, although the state dictated what the code of conduct of barefoot doctors should be, and what the ideal ratio of barefoot doctors to population should be (normally 1 barefoot doctor for every 500 people was recommended), provision was also made for the local commune to decide the number of barefoot doctors according to local conditions (DAHF, 1980, p.63). ${ }^{11}$ For example in more dispersed communes, it might be convenient to have more barefoot doctors for fewer people, simply because of the inconveniences of travel between the patients. Selection, training programmes and re-training refresher courses were therefore organised according to local judgements (DAHF, 1980, article 16, p.63). Organisationally then, despite the power of the state ideology and state responsibility for 'broad policy, technical direction and financial support' at a county and provincial level, the original RCMS was publically promoted as being 'decentralized and flexible, in keeping with the principles of self-reliance' and providing 'full opportunities for peripheral units to solve their own problems.' (WHO, 1978). This can well be read with the lenses provided by Mintzberg (1993) to observe the role of ideology, power, decentralisation and flexibility in organisational design (Zeffane, 1989).

Furthermore, if one looks at the way personnel actually operated, it is clear that there was no real autonomy. The barefoot doctor's role was more one 'of execution rather than of conception or supervision'. ${ }^{12}$ Although simple decisions were in the hands of the individual to decide how to treat the patient, in fact these rarely went beyond the purview of the extremely limited immediacy of the doctor-patient relationship. Any wider decisions on when to conduct vaccination campaigns, when to perform public sanitation campaigns, the content of health education programmes were all determined at a commune level. These decisions were guided by government policy (the most obvious expression of which being the edict to promote the one child policy, see Annex 2) (DAHF, 1980, Article 3, points $1 \& 6$, p.62). In 
terms of Institutional Theory (Powell and DiMaggio, 1991; Jepperson, 1991), the local branches of the RCMS were subject to organisational isomorphic pressures of all three kinds: coercive, normative, and mimetic (Scott, 1995). Local officers and doctors were forced to follow the policies and the orders (coercive), many of them might truly believe in the system (normative), most of them wanted the organisational unit under their responsibility to look pretty much the same (Suchman, 1995) to the other parts of the system (mimetic).

The differences however, between the old and the new schemes seem in this regard perhaps more slight than one might necessarily assume. Indeed, although the NRCMS emphasised the role central government had to play in funding subsidies, it nevertheless organised itself in a way surprisingly similar to that of the RCMS. For sure, the new scheme was organised around larger operational units at the county level (rather than at a village level as during Mao's time), but nevertheless the emphasis of the NRCMS is still on decentralisation (Mintzberg, 1993; Zeffane, 1989). Local decision-making and experimentation are promoted above any single state policy (Wagstaff et al, 2009). In a sense the distinctions are subtle - in the old RCMS the state promoted local initiative, did not fund the scheme centrally, but ultimately dictated its policies. In the NRCMS, the state also talks of local responsibility, but this time funds the scheme centrally, and still dictates general policies, but in a way less ideologically heavy-handed than that experienced under Mao.

Finally, mention needs to be made of the way the schemes had different financial structures. The RCMS was a prepaid medical service but one that essentially conformed to structures typical of co-operatives in other national contexts in that it was based upon a cofinancing, risk sharing approach to disease control (Bloom and Gu, 1997b). Local people paid an annual membership fee - which varied slightly between regions, but was from 0.35 Yuan to 3.60 Yuan per year. This amount represented between less than 1 and 3 per cent of a family's disposable income (Zhu et al., 1980, p.431-441). Some other subsidy was available from brigade and commune funds, but the government itself made no payments to the RCMS, except exceptionally in the very poorest regions (Zhu et al, 1989, p.432). Communes supplied the RCMS with housing, equipment and essential drugs from commune-owned estate and public welfare funds. The financial contributions received from the peasants were used locally to pay healthcare costs and the costs of medicine. Their local commune considered the contribution of barefoot doctors voluntary, with them receiving no payment for their health work specifically, rather only for their agricultural work.

This is a big contrast to the way that the NRCMS is financed and funded in modern China. In the new voluntary system contributions are paid at a flat-rate per household, and 
while all contributions are then in turn subsidized by government funds, both at a county and national level, the very poorest members of the community have their contributions entirely subsidized by the government (Wagstaff et al., 2009, p.3).

Membership to the RCMS was not theoretically obligatory, but the political structures in place greatly encouraged it. Whereas in the 1960s membership was entirely voluntary on an individual basis, from 1971 once a brigade had voted to join the system all members of that brigade found themselves to automatically be part of the scheme and their payments would be expected. Households were organized into teams, then teams formed brigades, and brigades formed the commune. This, essentially mandatory, necessity for enrolment in the scheme should be seen in marked contrast to the entirely voluntary membership promoted as an integral part of the NRCMS today. Mirroring the spread of market culture, perhaps even the slightly more democratic tendencies, starting to become acceptable in modern China today.

This tension between centralism and either apparent or true local initiative can be situated in the broader tradition of socialist organisations; 'This seemingly paradoxical leadership style was the translation of Leninist democratic centralism to the economic and organisational domains: a combination of centralized direction of the economy by the state with the democratic initiative of the people' (Tsoukas, 1994, p.35). But significantly, this also fits in with other scholarly work illuminating that China might not be as centralistic as it might appear to be in its institutional structures. Even within PRC, from the time of its very foundation, there appears to have been more space for innovation than the dominance of the State might suggest. Several bottom-up political innovations, protests, local bargaining and competition (Whiting 2000) still now continue to shape Chinese policies, values and organisations in ways unanticipated and unplanned from Beijing (Fairbank, 1998).

While the very hierarchical nature of the relationship between centre and periphery and between political and administrative level is still a strong characteristic of China, the NRCMS is no longer part of the huge bureaucratic and political machine of collectivist China (Annex 1 and 2). There is no army of Barefoot Doctors and the emphasis has shifted to be more on financial sustainability rather than creating an organisation fully integrated with state propaganda. Households and individuals are today subject to higher fluctuations of income and wealth. This has meant, for most, better living conditions but also more uncertainty about their futures. This is why the new scheme is perceived as an insurance against catastrophic healthcare expenses (Yip and Hsiao, 2009; Babiarz et al., 2010) in the eyes of both the policy makers and the subscribers. This hope is interesting because it is paradoxically reliant on 
historical foundations no longer considered relevant for modern China. Although cast differently, several organisational and ideological continuities between the two systems can be discerned. The next sections will describe the theoretical and practical implications of our findings and the needs for further research on this topic. 
DISCUSSION: HISTORY AND ORGANISATION STUDIES

Answering the research questions, we have specifically addressed a gap in the existing literature on the NRCMS, as most medical, political, and economic studies have avoided analysing the heritage of the Maoist version of the scheme when investigating the current one. We consider this to miss a vital part of the story. It is intriguing to look at historical precedents in the light of the dramatically abrupt fall of the past scheme. The subsequent and sudden rehabilitation of the system in 2002, without any apparent mention in the public documents about the past scheme, but clearly embodying a strong ideological similarity to the former incarnation, we argue, needs to be considered. Organisation Theory, when combined with historical analysis can offer further insights into the understanding of organisational reality. Institutional Theory has also been drawn upon to provide insights on the way that these organisations emerged, diffused, disappeared and reappeared under a new institutional context (Powell and DiMaggio, 1991; Jepperson, 1991).

In the past thirty years there have been increasing calls advocating the wider use of historical research methods of analysis within social science disciplines, particularly those within Management Studies, Organisational Studies and Institutional Theory (Kieser, 1994; Gherardi and Strati, 1988; Decker, 2013; Wadwani and Bucheli, 2013; Rowlinson et al., S. 2014; Greenwood and Bernardi, 2014).

This work responds to these calls, arguing that NRCMS events are both historically contingent and contingent upon modern socio-political dynamics. As it has been argued among historians and organisational studies scholars (Greenwood and Bernardi, 2014, Rowlinson et al., S. 2014), using historical methods does not mean abandoning discrete disciplinary differences between historically separate fields of enquiry. Indeed, we do not expect any sort of seamless integration between two fields. To this end, we use the example of comparing and contrasting the old and new incarnations of the Chinese Rural Co-operative Medical Scheme using both historical methods and Organisation Theory. Our recent visits to rural clinics in China have given us the contemporary perspective, but this is less meaningful if we do not also use history to assess the place from which the new organisational structures and ideological commitments of the scheme have evolved. While history gives us the toolkit to assess change over the passage of time, Organisation Studies can additionally give us the means to further critique this analysis by allowing us to examine the structures and power relations that have been present in both schemes.

This study has a few limitations. The language barrier meant we only had access to interviews and Chinese Mandarin documents through the mediation of a translator. 
Furthermore the understanding of Chinese politics is a very complex exercise that we make no special claims to have mastered. Finally, the understanding of the Chinese co-operative movement itself presents several challenges, not least because it is so different in many fundamentals to international model that we assume as a paradigm.

These limitations should be seen as signals for the need for further research. The Chinese co-operative movement deserves more research; it is not clear how much it is in line with the international co-operative movement. As well deserves further research the relationship between contemporary communist leadership and Maoism. Also the measurement of the effectiveness and efficiency of the NRCMS should be investigated further; twelve years after the establishment, its successes and failures shall be visible. 
IMPLICATIONS: THEORY, PRACTICE, POLICY

This research conveys implications for theory (the need of an historical approach in contemporary Chinese Studies), for practice (the need of modernisation for the Chinese cooperative movement) and for policy (the effectiveness and efficiency of NRCMS).

With regards to theory we have learnt that no studies to date have examined the modern system directly comparative to the older one. In particular, most analysis has focused either on the financial or the medical side, without considering the ideological component of the old system and its inheritance to the NRCMS. The later scheme may have differed in emphasis but broadly followed historical patterns in its structure and priority. There were key differences in political context, organisational priorities and membership terms between the two models, but nevertheless it is arguable that the NRCMS relied on its historical antecedents as part of its modern story of national acceptance. Certainly it seems that the original scheme has left an ambiguous legacy, on one hand its demise was nationally seen with a large amount of regret, certainly if we are to believe the Party line, emanating from the Department of Health which stated that the decline of the RCMS was ultimately to be regretted because the majority of farmers had welcomed this system (Zhang, 1982, p.32). Yet also by understanding the close associations the earlier scheme had with Maoism and enforced collectivisation, we are able to see why there maybe some resistance to cooperatives within modern China. We realise that the health co-operatives that functioned during the 1960s are of a different nature to the NRCMS embraced in 2002. Yet to view modern developments in a vacuum is to ignore an important part of their rationale. Even when contemporary models are significantly different from their forerunners, their divergences from similar past conceptions should be seen as much as a reaction to historical precedents, as it is an adjustment to the social and political factors of the contemporaneous context. Chinese institutions are very ritualistic (Weber, 1951) and have a very long memory (Douglas, 1987); this makes the understanding of the past very important issue.

With regards to practice, our story of the resurrection of a Maoist co-operative model in post-Maoist China says much about the way co-operatives can adapt, survive and flourish in different political climates (Scott, 2003). Propagandist intent is no longer a central driving force of the new scheme, but nevertheless is present in a subtler and less obvious form. The language has changed from one of collectivism to individualism (all be it with State protection); the spirit of the new scheme is one of voluntary participation and selfresponsibility, except for the very poorest sectors of society. The organisation seems to have centralised, whilst also simultaneously becoming less authoritarian in its public demands. As 
explored in section 4 however, organisational differences are perhaps not so bold as the government would have us believe. The 2002 NRCMS policy, together with the 2007 Specialized Farmers Co-operative law, represent the evident resurgence in interest of contemporary Chinese governments in the co-operative organisational model. The comparison of the old and new Rural Co-operative Medical Scheme confirms that China is indeed involved in a process of convergence (Scott, 1995) towards the western notion of cooperation. The reputation of cooperatives was severely damaged by the ieological rule of Mao, but nevertheless the contemporary Chinese co-operative movement, although different, owes much more than it would like to admit to its troubled past. Further convergence to the international co-operative model will require to deal with that past.

With regards to policy, we have learnt that both schemes have been measurably effective in delivering a broad improvement of health conditions in rural China. Having said this, on the efficiency side, the results are less clear-cut. The measurement of efficiency and effectiveness is beyond the boundaries of this work and would involve broad statistical analysis of the data before and after these schemes were implemented. Leaving the judgement on the efficiency to economics studies, and the judgement on the effectiveness to public medicine studies, we can, however, add to the debate the useful point that (however effective) the organisational form adopted is never neutral, both because of its past heritage and also because of its contemporary influences and objectives. This means that in this case, as in others, the effectiveness and efficiency of Chinese social and economic policies may be affected by the degree of modernization and transparency on politics, ideology and past Communist leaderships. 
This paper has described the old and the new Rural Co-operative Medical Scheme. After a detailed narration and historical contextualization, the data analysis made it possible to answer both research questions. We have shown that ideologically and organisationally both schemes are crucially different. However, we argue, these differences are perhaps not that large.

The new Rural Co-operative Medical Schemes is not an ideologically run health care provider, but it nevertheless is far from ideology free. Vitally, under the administration of the national and local authorities, the influence of politics is still visible (as in many other economic sectors) and the Chinese Communist Party are, of course, still conveying some ideological messages, all be they modernised by the new language of individual responsibility and the persuasive appeal of the image of providing a universal entitlement to basic health care. By comparing the ideological commitments of both of the schemes we can see a distinct reduction in the direct use of political ideology as a cohesive rationale for not only the modern scheme itself, but also for the way it is run and staffed at a micro-level. The NRCMS is still, for sure, part of the policy template put forward by the politicians of modern China, but it is one that now prioritises long term health affordability and community healthcare management above the need to publicise and justify the central regime.

The old and new RCMS are not similarly organised in the core way the NRCMS has aligned itself closer to the western model of mutual insurance. In fact, most of the structure and maintenance of healthcare and public medicine operations is no longer directly managed by the NRCMS. The new incarnation of the scheme is closer now to western models of mutual insurance than it ever has been at any previous point. Political emphasis has shifted and in turn so have consumer expectations. China is now no longer inward looking, but as the second largest economy and a key player in the modern world stage, is attempting to apply broadly western models of insurance to tackle its population challenges.

This work has also argued that using history, as core part of the analytical method, can give deeper insights to organisation and management scholars working on contemporary Chinese policies and business practices. 
${ }^{1}$ Original Chinese: ‘至于如何解决广大农民的医疗卫生问题, 那时共产党只有一个粗略的思路, 既是走 合作的道路'

2 ‘生产建设与和平生活就无从获得保障’, He Cheng, Deputy Minister of Health, quoted in Yi Hu (2007) p.51.

${ }^{3}$ Original Chinese: ‘要把过去两年放松了的爱国卫生运动重新发动起来, 并且一定要于一九六 0 年, 一 九六一年, 一九六二年这二年内做出显著的成绩' quoted from Mao Z., Instructions for Public Health/关于 卫生工作的指示, 18 March 1960.

${ }^{4}$ WHO/E/5/418/11 Somnuek Unakul, Report on Rural Sanitation in China, February 1975, p.3.

${ }^{5}$ WHO/AFR/MCH/66 3.9.75 V. Agbessi, 'Organisation of Health Services in China; Report on a Mission, 21 October 1974, p.2.

${ }^{6}$ Original Chinese: ‘农村合作以来哦是人民公社社员依靠集体力量, 在自愿互助的基础上建立起来的一 种社会主义性质的医疗制度, 是社员群众的集体福利事业', [Article 1].

${ }^{7}$ Original Chinese: ‘尤其应优先挑选具有上述条件的贫下中农子女.’

${ }^{8}$ Original Chinese: ‘合作医疗站是集体福利事业单位, 不用办成企业及副业, 也不应要求他们上缴利润' [Article 10].

${ }^{9}$ See also The Shanghai Porpaganda Poster Mueum and the website database curated by Marien van der Heijden: http://chineseposters.net/.

${ }^{10}$ Original Chinese: “举办合作医疗的形式要根据当地的实际情况和条件, 经社员群众充分讨论决 定'[Article 10].

${ }^{11}$ Original Chinese: ‘赤脚医生的人数，应根据实际需要进行配备’, [Article 13].

${ }^{12}$ WHO/N52/180/2 CHN (2), File 1, WHO Study Missions to China, 1973-1978, 'Medical Care in Rural Areas', p.2. 


\section{REFERENCES}

BABIARZ KS, MILLER G, YI H, ZHANG L, ROZELLE S., 2010. New evidence on the impact of China's New Rural Co-operative Medical Scheme and its implications for rural primary healthcare: multivariate difference-in-difference analysis. British Medical Journal, Oct 21;341:c5617.

BLOOM G., GU X.Y., 1997a, Health Sector Reform: Lessons from China. Social Sciences and Medicine, 45, pp.351-360.

BLOOM G., GU X.Y., 1997b, Introduction to Health Sector Reform in China, IDS Bulletin, 28(1), pp.1-11.

BROWN P., THEOHARIDES C., 2009, Health-Seeking Behavior and Hospital Choice in China's New Co-operative Medical System. Health Economics, Vol. 18.

BROWN P.H., DE BRAUW A., DU Y., 2009. Understanding Variation in the Design of China's New Co-operative Medical System, The China Quarterly 198, pp.304-329.

BRYANT J.H., 1978. Community Health Workers: The Interface between Communities and Health Care Systems. WHO Chronicle, 32, pp.144-148.

CAI T.X., 2009, 新中国成立以来我国农村合作医疗的发展历程 The History of the Development of the Rural Co-operative Medical Care System since the Foundation of PRC. Literature of Chinese Communist Party No.3 pp.20-26.

CENTRAL POLITICAL BUREAU, 1978, Document No.37, 23 June 1978, "Report on Reducing the Farmer's Unreasonable Financial Burden in Xiangxiang County, ‘关于 湘乡县减轻农民不合理负担的调查报告, cited in Wu, S., 2005, p.4; see also, People's Daily, 5 July 1978, p.1.

COOK I., CLEGG J., 2012, "Shared Visions of Co-operation at a Time of Crisis: The Gung Ho Story in China's Anti- Japanese Resistance", in Webster A., Brown A., Stewart D., Walton J.K., Shaw L., The Hidden Alternative: Cooperative Values, Past, Present and Future, United Nations University Press, Helsinki.

CPC Central Committee and State Council, 2002, The CPC Central Committee and the State Council 's Decision on Further Strengthening the Rural Health Work. 中共中央国务 院关于进一步加强农村卫生工作的决定 CPC Central Committee and State Council Document 中发 No.13, Beijing 北京.

CHENG-CHUNG L., 1988, European Co-operativism in Chinese Perspective, Annals of Public and Co-operative Economics, Volume 59, Issue 3, pages 369-377. 
CHINESE MINISTRY OF HEALTH, 1983, 1984, 2000, Year Books of Health in the People's Republic of China, People's Medical Publishing House, Beijing.

CROZIER M., 1963, Le phénomène bureaucratique, Paris, Le Seuil.

DAHF, 1980, Department of Agriculture, Health and Finance, together with State Administration of Medicine 'Code of Conduct of RCMS'. Fujian Medical Journal, 3. DECKER S., 2013, 'The Silence of the Archives: Business History, Post-colonialism and Archival Ethnography', Management and Organizational History 8: 155-73.

DEPARTMENT OF HEALTH, 1976, Conference Report, 15 June to 23 June 1976, cited in: Xia, X., 2003, p.110.

DEPARTMENT OF HEALTH, 1965, Report Prioritizing Primary Level Medical Services to Rural Areas /关于把卫生工作重点放到农村的报告. 21 September 1965.

DONG C., KAM K.T., LIFENG Z., YUHONG Z. 2013, Will China's Co-operative Medical System fail again? Insight from farmer satisfaction survey. Health Promotion International.

DOUGLAS, M., 1987, How Institutions Think, London, Routledge.

FAIRBANK J.K., FEUERWERKER A., 1986, editors, The Cambridge History Of China, Vol. 13, Part 2, Cambridge.

FAIRBANK, J.K., 1998, China: a New History. Belknap Press of Harvard University Press, Cambridge, Massachusetts.

GAO S., CHI F., 1996, The Development of China's Non Governmentally and Privately Operated Economy, Languages Press, Beijing.

GENERAL OFFICE OF THE STATE COUNCIL, 2003, Suggestions on the Establishment of New Rural Co-operative Medical System 关于建立新型农村合作医疗制度的意 见 The Document of General Office of the State Council 国办发.No.3.

GERTLER, P., GRUBER, J., 2002. Insuring consumption against illness. The American Economic Review, 92(1), 51-70.

GHERARDI, S., STRATI, A., 1988. The Temporal Dimension in Organizational Studies', Organization Studies 9: 149-64.

GREENWOOD A., BERNARDI, A., 2014. Understanding the rift, The (still) uneasy bedfellows of History and Organization Studies, Organization.

HO D.Y.F., 1978. The Concept of Man in Mao-TseTung's Thought, Psychiatry, 41, pp.391402. 
HU Y., 2007, Disease, Politics and State Construction 疾病、政治与国家建设, PhD Thesis, Huazhong Normal University.

HUANG S.M., 1988, Transforming China's Collective Health Care System: A Village Study, Social Science and Medicine, 27, pp.879-888.

JAMISON D.T., EVANS J.R., KING T., PORTER I., PRESCOTT N., 1984, China: The Health Sector, World Bank, Washington DC.

JEPPERSON R.L., 1991, Institutions, institutional effects and institutionalism, in Powell and DiMaggio, The New Institutionalism, 143163.

KIESER A., 1994, 'Why Organization Theory Needs Historical Analyses and How this Should be Performed', Organization Science 5(4): 608-20.

KLOTZBÜCHER S., LÄSSIG P., JIANGMEI Q., WEIGELIN-SCHWIEDRZIK S., 2010. What is New in the "New Rural Co-operative Medical System"? An Assessment in One Kazak County of the Xinjiang Uyghur Autonomous Region, The China Quarterly, Special Section on Social Insurance in China, 201, pp.38-57.

KORNAI J., YINGYI Q., edited by, 2009, Market and socialism: in the light of the experiences of China and Vietnam. IEA, Palgrave Macmillan.

LAMBO T.A., 1980, Politics, Ideology, and Health: Reflexions Arising from a Study Tour of the People's Republic of China by Six African Ministers of Health. World Health Forum, 1.1, pp.5-7.

LANDSBERGER S.R. AND VAN DER HEIJDEN M., 2009, Chinese Posters, Munich, Berlin, London, New York: Prestel.

LI, Y., A 1985, Country Physician. World Health, Jan/Feb. pp.4-5.

LIU Y., 2004, "Development of the rural health insurance system in China", Health and Policy Planning, 19(3): 159-165.

MAO, Z., 1956, Model Guidelines on Agricultural Production Co-operatives/高级农业生产 合作社示范章程 30 June 1956.

MAO Z., 1958, Decision on Setting up the People's Commune in Rural China/ 中共中央关 于在农村建立人民公社问题的决议', 29 August 1958.

MAO Z., 1960, Instructions for Public Health/关于卫生工作的指示, 18 March 1960.

MAO Z., 1965, Directive on Public Health, 26 June 1965, ‘中央关于卫生工作的指示/ 1965 (quoted in Mao, 1996, p.80).

MAO Z., 1968. The Analysis of the Reform of Medical Education from the Perspective of the Growth of the Barefoot Doctor: An Investigation Report in Shanghai 从“赤脚医生” 
的成长看医学教育革命的方向:上海市的调查报告, Redflag Journal 红旗杂志 Vol.3, pp.1-3. The People's Publisher $1^{\text {th }}$ Edition 人民出版社 1 版.

MAO Z., 1991. Selected Works of MAO TSE-TUNG 毛泽东选集 Volume3 People's Publisher $2^{\text {th }}$ Edition 人民出版社第二版.

MAO Z., 1996, Manuscripts of Mao Zedong Since the Foundation of the PRC Vol. 9 建国以 来毛泽东文稿 第九卷 Central Literature Publishing House 中央文献出版社 Beijing 北京.

MERTON R.K., 1936, The Unanticipated Consequences of Purposive Social Action, American Sociological Review 1/6:894-904.

MINTZBERG H., 1993, Structure in fives: Designing effective organizations, Englewood Cliffs, NJ, US: Prentice-Hall.

PRC, 1978, Constitution of the People's Republic of China. Beijing, pp.1-45.

POWELL, W.W., and DiMaggio P.J., ed. 1991, The New Institutionalism in Organizational Analysis, University of Chicago Press.

PRESCOTT, N., JAMISON, DT., 1984. Health Sector Finance in China. World Health Statistics Quarterly, 37, pp.387-97.

QIN L., PAN S., WANG C., JIANG Z., 2012, Adverse selection in China's New Rural Cooperative Medical Scheme, China Agricultural Economic Review, Vol. 4 Iss: 1, pp.69 $-83$

ROWLINSON, M., HASSARD, J., DECKER, S., 2014. 'Strategies for Organizational History: A Dialogue Between Historical Theory and Organization Theory', Academy of Management Review.

SCOTT W.R., 1995, Institutions and Organizations, SAGE, Thousand Oaks, CA.

SCOTT W.R., 2003. "Institutional carriers: Reviewing modes of transporting ideas over time and space and considering their consequences," Industrial and Corporate Change 12: 879-94.

SHENKAR O., 1996, The Firm as a Total Institution: Reflections on the Chinese State Enterprise. Organisation Studies, 17, p.885-907.

SKEET, M., 1984, Community Health Workers: Promoters or Inhibitors of Primary Health Care? World Health Forum, 5, pp.291-295.

SUCHMAN M.C., 1995. "Managing legitimacy: Strategic and institutional approaches," Academy of Management Review 20:571 610 . 
TSOUKAS H., 1994, Socio-Economic Systems and Organisational Management: An Institutional Perspective on the Socialist Firm. Organisation Studies, 15, pp.21-45.

UNITED NATIONS, 2013, China's progress towards the Millennium Development Goals 2013 Report, with Ministry of Foreign Affairs of the People's Republic of China, Beijing.

UNDP, 2013, China Human Development Report. 2013: Sustainable and Liveable Cities: Toward Ecological Urbanisation, Compiled by United Nations Development Program, Beijing.

WADWANI, R.D., BUCHELI, M., 2013, Organizations in Time: History, Theory, Methods. New York, NY: Oxford University Press.

WAGSTAFF A., LINDELOWB M., JUNC G., LINGC X, JUNCHENGCET Q., 2009. Extending Health Insurance to the Rural Population: An Impact Evaluation of China's New Co-operative Medical Scheme, Journal of Health Economics 28 pp.1-19.

WAGSTAFF A., LINDELOW M., 2005, Can Insurance Increase Financial Risk? The Curious Case of Health Insurance in China, World Bank Policy Research working Paper, 3741.

WANG S., 2008, Learning and Adapting: The Case of Rural Healthcare Financing, Department of Government and Public Administration, the Chinese University of Hong Kong and School of Public Policy and Management, Tsinghua University, June, pp.1-45.

WANG H., YIP W., ZHANG L., WANG L., HSIAO W., 2005, Community-based health insurance in poor rural China: the distribution of net benefits, Health Policy and Planning, November, 20 (6): 366-374.

WEBER M., 1951, The Religion of China: Confucianism and Taoism, The Free Press, Clencoe, Illinois.

WHITING S.H., 2000, Power and Wealth in Rural China: The Political Economy of Institutional Change. Cambridge University Press, Cambridge MA.

WHO, 1973, Report of WHO Study Mission to People's Republic of China, World Health Organisation, Geneva.

WHO, 1978, Organisation and Functioning of the Health Services in China: Report on Two WHO Study Missions to the People's Republic of China 1973 and 1974. World Health Organisation, Geneva.

WHO, 1974, Round Table Discussion: WHO Visits China. World Health, September, pp.815. 
WHO, 1988, Community Health Workers: Strengthening Community Health Workers for Health for All. Weekly Epidemiological Health Record, 63, 35, pp.265-68.

WHO, 1989, Co-operative Medical System and Barefoot Doctors in Rural China. Bulletin of the World Health Organisation, 87, 4, pp.431-41.

WHO, 2000, Health Systems: Improving Performance. The World Health Report, Geneva.

YIP W. AND HSIAO W.C., 2009. Non-evidence-based policy: How effective is China's new co-operative medical scheme in reducing medical impoverishment? Social Science \& Medicine, 2009, vol. 68, issue 2, pp.201-9.

ZEFFANE R.M., 1989, Centralization or Formalization? Indifference Curves for Strategies of Control, Organization Studies 10: 327.

ZHANG, H.Y. (張禹罕), 1982. Public Health 公共卫生学, Taiwan Commercial Press. 台湾 商务印书馆.

ZHANG, K.N., WEN, Y.Q., LIANG, P. edited by, 张开宁, 温益群, 梁苹 (编) 2002, From Barefoot Doctors to Village Doctors 从赤脚医生到乡村医生 Yunnan People's Publishers 云南人民出版社 Yunnan City 云南.

ZHU, N., LING, Z., SHEN, J., LANE, JM., HU, S., 1989, Factors Associated with the Decline of the Co-operative Medical System and Barefoot Doctors in Rural China, Bulletin of the World Health Organisation, 87, 4, pp.431-441. 
FIGURES AND TABLES

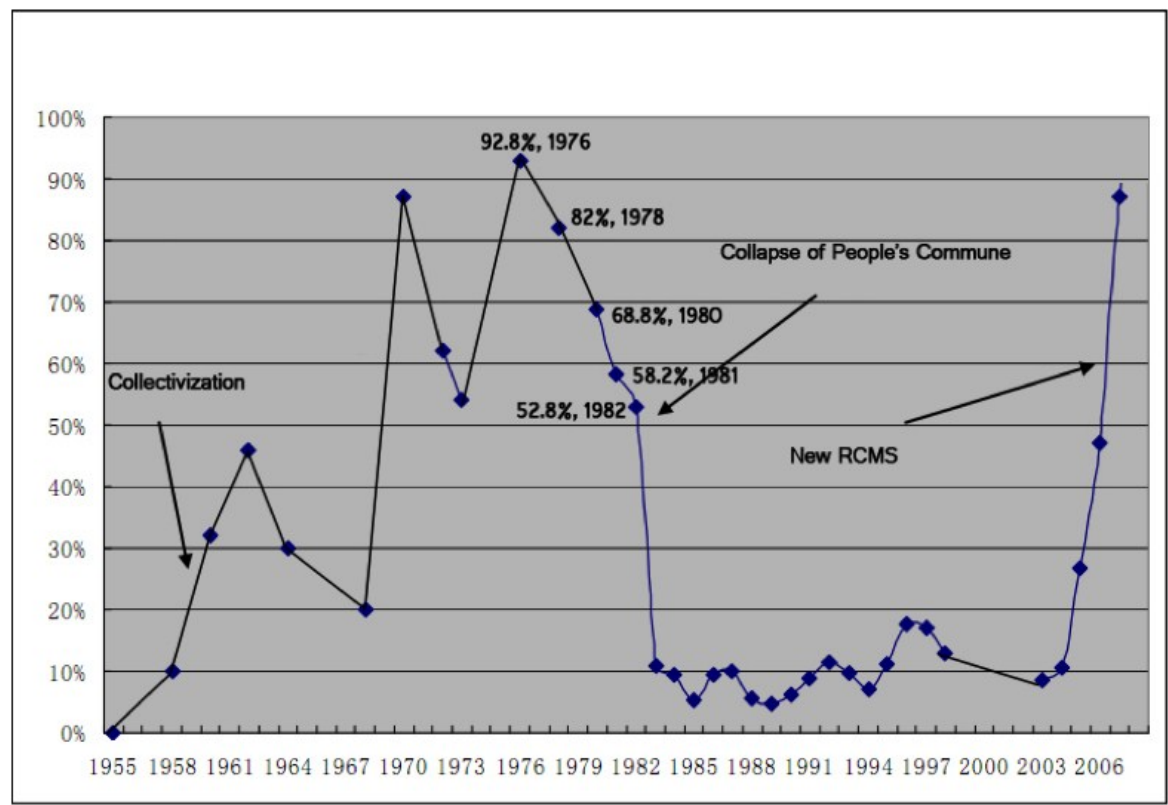

Figure 1, Rise and fall of the Rural Co-operative Medical Scheme: percentage of participation among local level administrative units in rural China (LIU, 2004). 


\begin{tabular}{|c|c|c|c|c|c|c|c|c|c|c|c|c|c|c|c|c|c|c|c|c|}
\hline & ڤ్ & 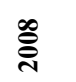 & 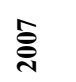 & ‡్丶ે & 气ั้ & 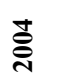 & ڤ్ & 气్๊ & 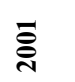 & ఫ్ & ڤे & $\stackrel{\infty}{2}$ & $\hat{\sigma}$ & $\stackrel{2}{2}$ & ڤ̆ & ğ & $\tilde{g}$ & $\tilde{\sigma}$ & $\bar{g}$ & ڤิ \\
\hline $\begin{array}{l}\text { Private expenditure on health as a percentage of } \\
\text { total expenditure on health }\end{array}$ & 49.9 & 52.7 & 54.7 & 59.3 & 61.2 & 62.0 & 63.8 & 64.2 & 64.4 & 61.7 & 59.1 & 58.2 & 55.8 & 53.4 & 49.5 & - & - & - & - & - \\
\hline $\begin{array}{l}\text { General government expenditure on health as a } \\
\text { percentage of total expenditure on health }\end{array}$ & 50.1 & 47.3 & 45.3 & 40.7 & 38.8 & 38.0 & 36.2 & 35.8 & 35.6 & 38.3 & 40.9 & 41.8 & 44.2 & 46.6 & 50.5 & - & - & - & - & - \\
\hline $\begin{array}{l}\text { Per capita total expenditure on health at average } \\
\text { exchange rate (US\$) }\end{array}$ & 169 & 146 & 112 & 93 & 81 & 70 & 61 & 54 & 48 & 44 & 39 & 36 & 31 & 27 & 21 & - & - & - & - & - \\
\hline $\begin{array}{l}\text { Total expenditure on health as a percentage of gross } \\
\text { domestic product }\end{array}$ & 4.6 & 4.3 & 4.2 & 4.6 & 4.7 & 4.7 & 4.8 & 4.8 & 4.6 & 4.6 & 4.5 & 4.4 & 4.0 & 3.8 & 3.5 & - & - & - & - & - \\
\hline $\begin{array}{l}\text { Out-of-pocket expenditure as a percentage of } \\
\text { private expenditure on health }\end{array}$ & 82.6 & 82.6 & 82.6 & 83.1 & 85.3 & 86.5 & 87.6 & 90.0 & 93.1 & 95.6 & 94.5 & 94.3 & 94.8 & 94.8 & 93.7 & - & - & - & - & - \\
\hline $\begin{array}{l}\text { Social security expenditure on health as a } \\
\text { percentage of general government expenditure on } \\
\text { health }\end{array}$ & 66.3 & 66.3 & 66.3 & 57.3 & 54.1 & 55.2 & 53.4 & 54.8 & 55.1 & 57.2 & 54.2 & 55.8 & 60.4 & 62.1 & 64.2 & - & - & - & - & - \\
\hline $\begin{array}{l}\text { Polio (Pol3) immunization coverage among 1-year- } \\
\text { olds (\%) }\end{array}$ & 99 & 99 & 94 & 94 & 87 & 87 & 87 & 86 & 86 & 86 & 86 & 85 & 85 & 84 & 82 & 87 & 90 & 93 & 95 & 98 \\
\hline $\begin{array}{l}\text { Private prepaid plans as a percentage of private } \\
\text { expenditure on health }\end{array}$ & 6.2 & 6.2 & 6.2 & 6.5 & 5.8 & 5.5 & 5.8 & 3.3 & 1.9 & 1.0 & 1.70 & 1.3 & 0.8 & 0 & 0 & - & - & - & - & - \\
\hline $\begin{array}{l}\text { Per capita government expenditure on health at } \\
\text { average exchange rate (US\$) }\end{array}$ & 85 & 69 & 51 & 38 & 31 & 27 & 22 & 19 & 17 & 17 & 16 & 15 & 14 & 12 & 11 & - & - & - & - & - \\
\hline Per capita total expenditure on health (PPP int. \$) & 309 & 265 & 234 & 215 & 191 & 170 & 152 & 135 & 117 & 107 & 95 & 85 & 73 & 62 & 52 & - & - & - & - & - \\
\hline Gross national income per capita (PPP int. \$) & - & 6010 & 5430 & 4700 & 4100 & 3590 & 3180 & 2830 & 2560 & 2330 & 2110 & 1950 & 1810 & 1640 & 1480 & 1340 & 1170 & 1020 & 890 & 800 \\
\hline
\end{tabular}

Table 1, Key indicators of wealth and well-being in China, 1990-2002-2009. Source: authors' selection and elaboration from WHO data. 


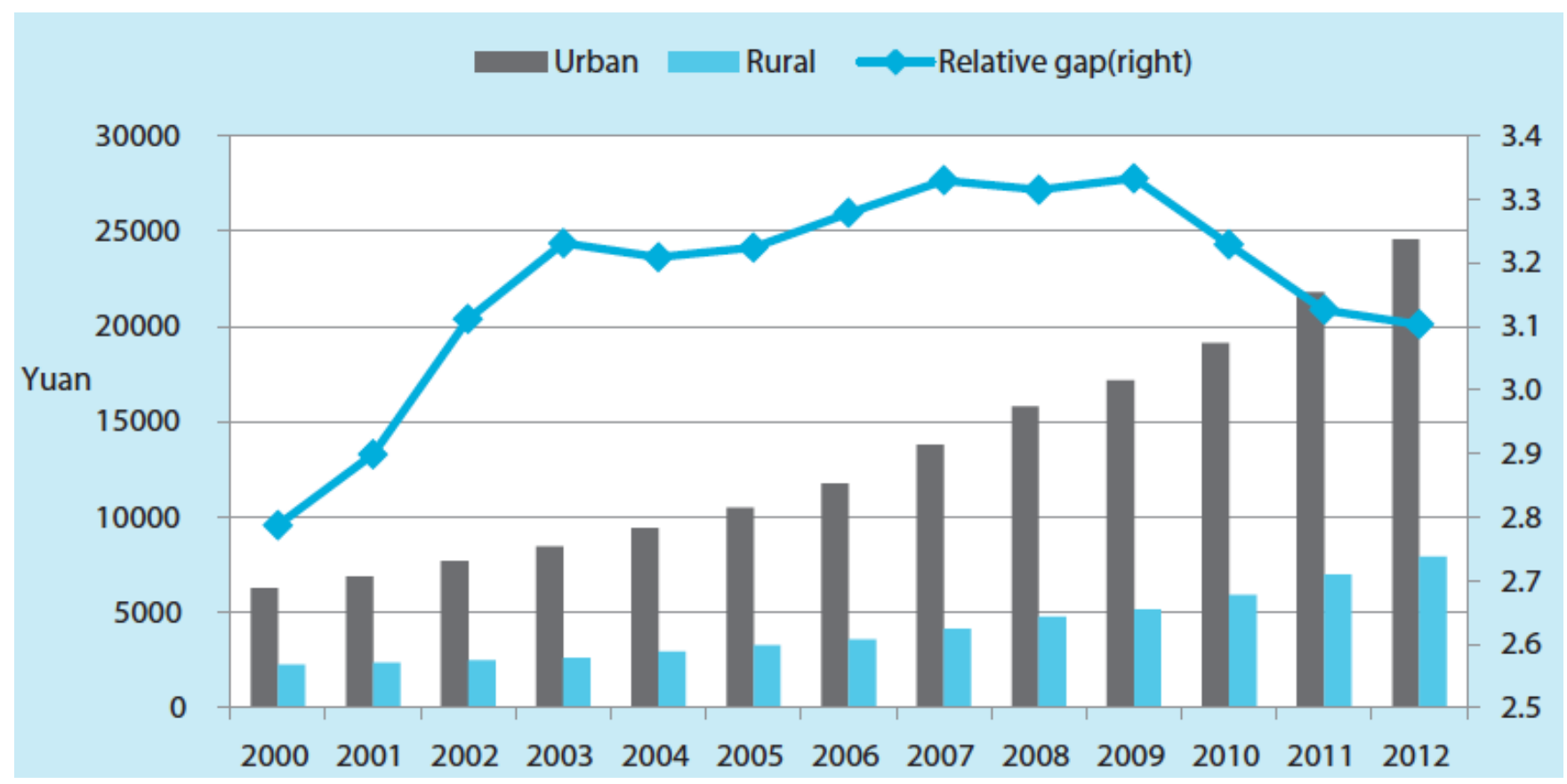

Figure 2, Absolute and relative gap of China's urban and rural residents' per capita income, 2000-2012. UNDP, 2013.

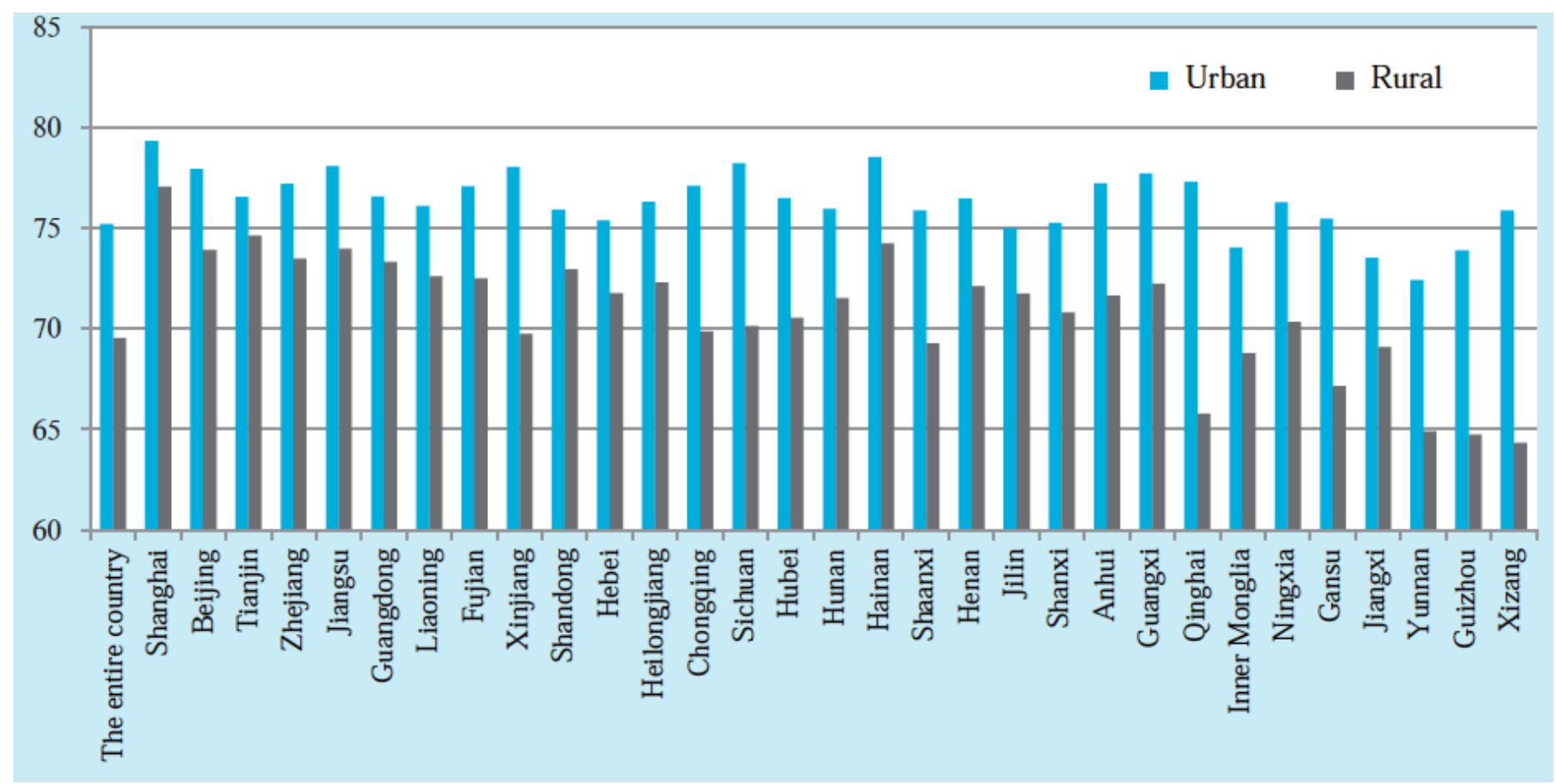

Figure 3, Urban and rural life expectancy by province or metropolitan areas in 2000 (UNDP, 2013). 


\section{ANNEXES}

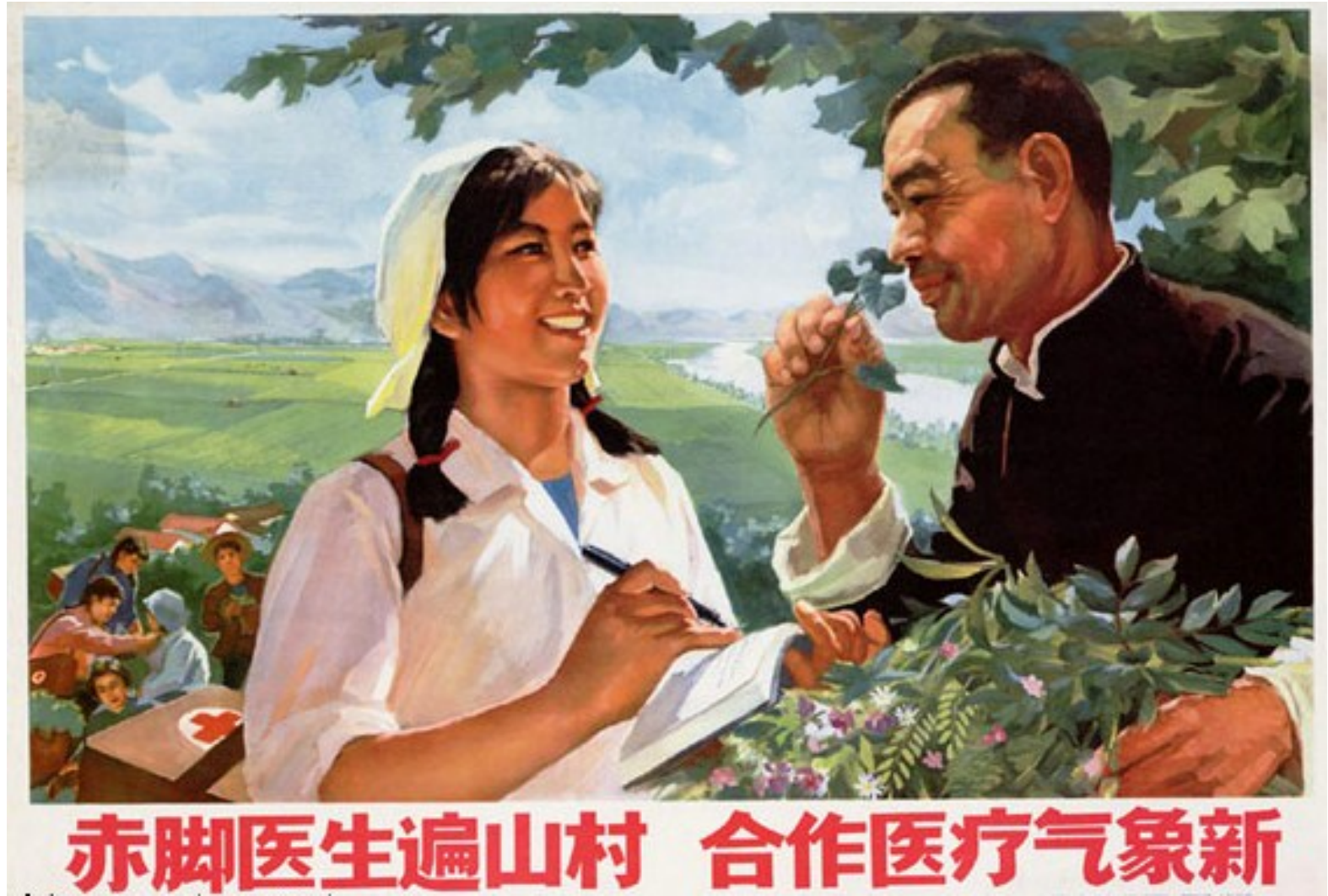

Annex 1: "Barefoot doctors are all over the mountain villages, cooperation creates a new atmosphere of medical treatment", 1974, van der Heijden Archive.

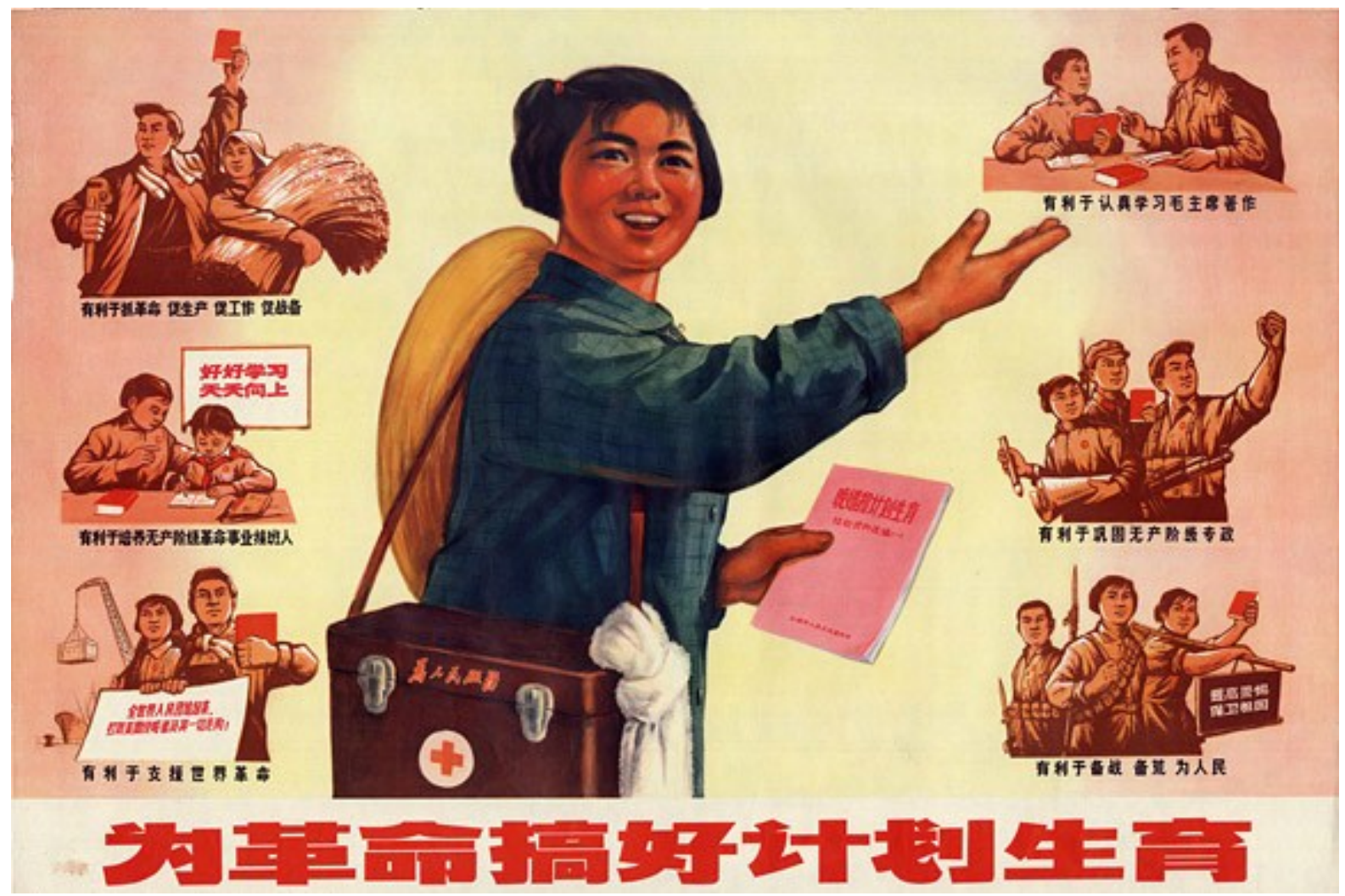

Annex 2: "Practice birth control for the revolution", 1972, van der Heijden Archive. 


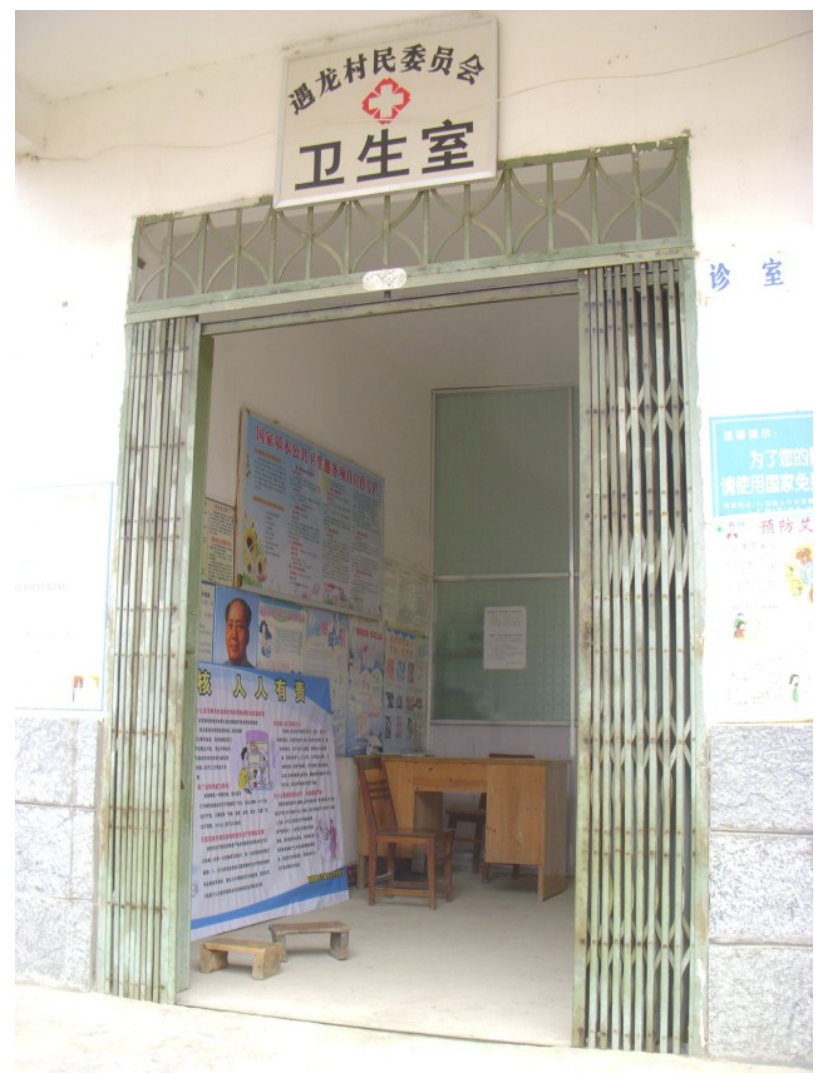

Annex 3: A clinic in Guanxi, 2012, photo taken by the authors.

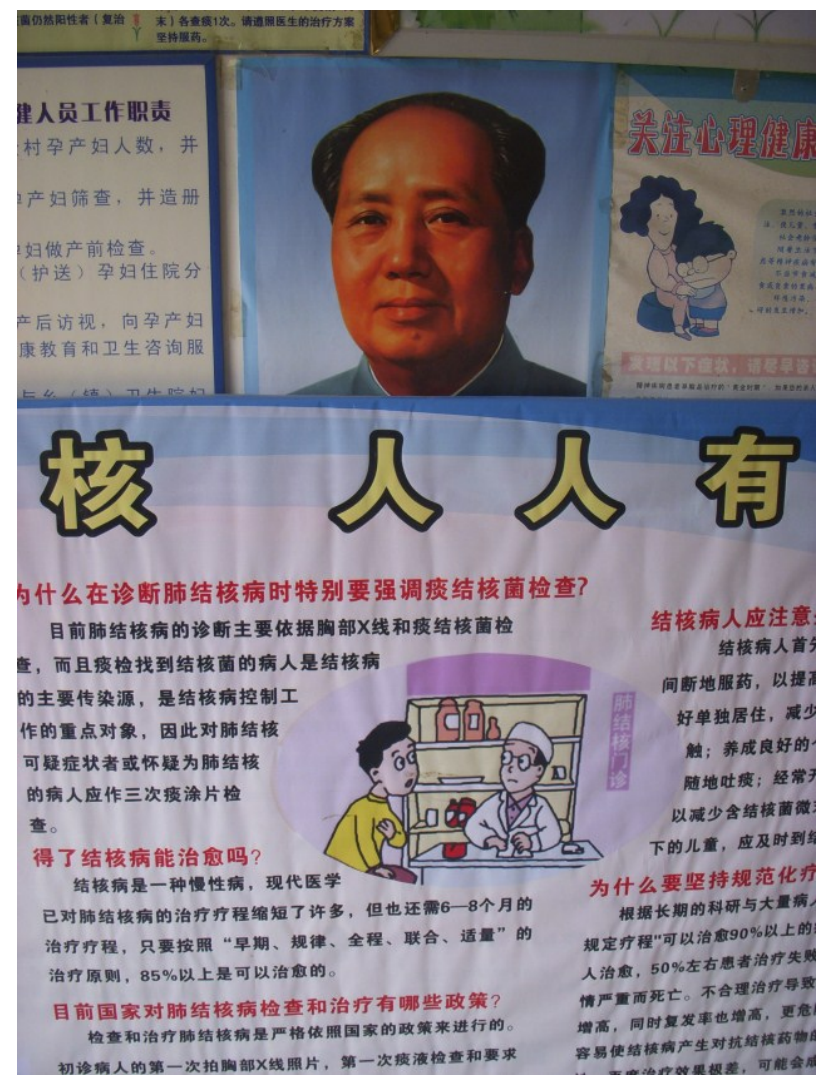

Annex 4: A picture of Mao Zedong in a clinic in Guanxi, 2012, photo taken by the authors. 


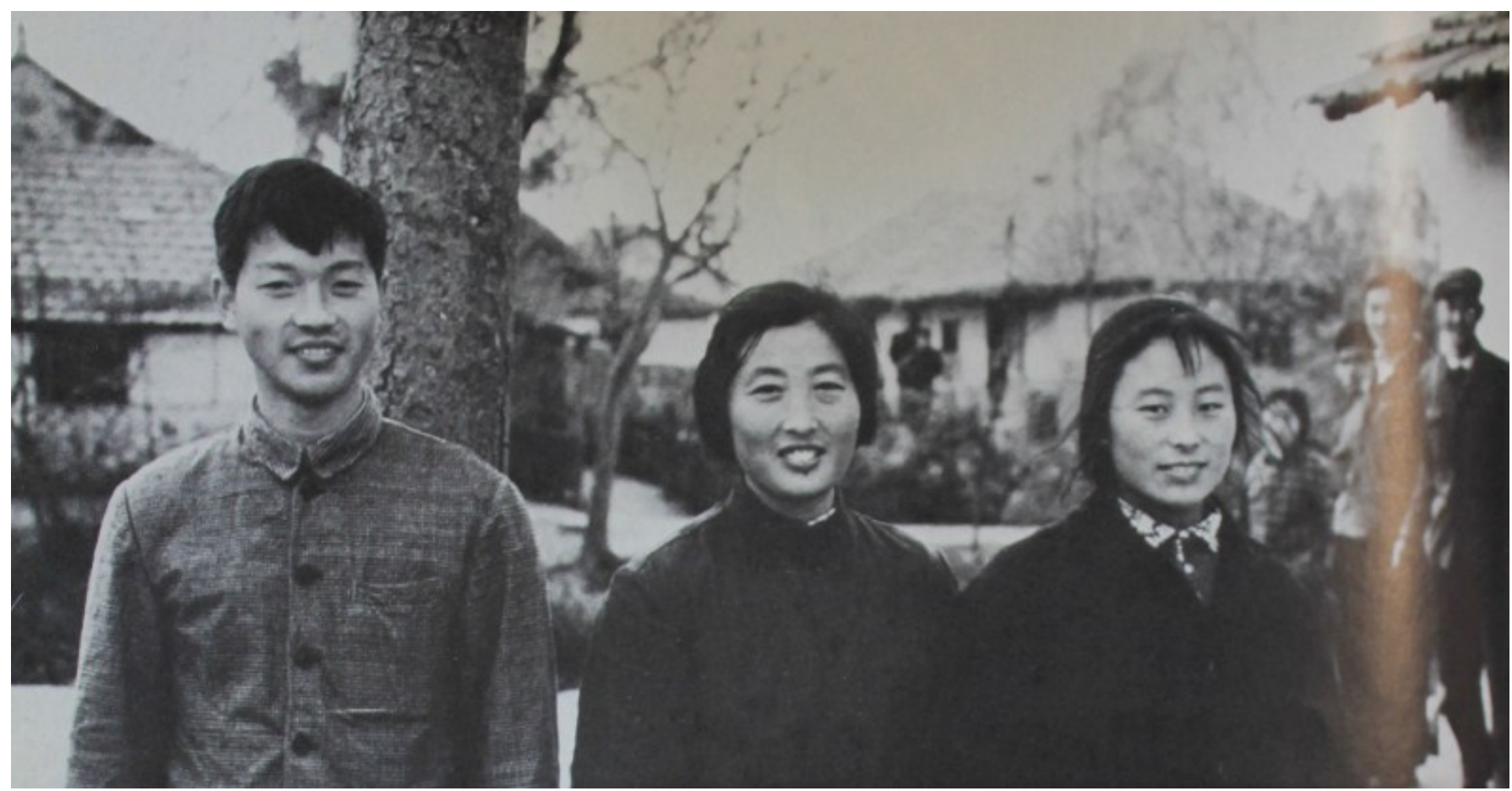

Annex 5: "Three barefoot doctors", 1974, from WHO Archive, WHO/N52/180/2 CHN (2), File 2, WHO Study Missions to China. 